Fixed Point Theory, 20(2019), No. 1, 211-232

DOI: $10.24193 /$ fpt-ro.2019.1.14

http://www.math.ubbcluj.ro/ nodeacj/sfptcj.html

\title{
COMMON SOLUTION TO A SPLIT EQUALITY MONOTONE VARIATIONAL INCLUSION PROBLEM, A SPLIT EQUALITY GENERALIZED GENERAL VARIATIONAL-LIKE INEQUALITY PROBLEM AND A SPLIT EQUALITY FIXED POINT PROBLEM
}

\author{
K.R. KAZMI, REHAN ALI AND MOHD FURKAN
}

\author{
Department of Mathematics, Aligarh Muslim University, Aligarh 202002, India \\ E-mail: krkazmi@gmail.com,rehan08amu@gmail.com, mohdfurkan786@gmail.com
}

\begin{abstract}
This paper deals with a strong convergence theorem for an iterative method for approximating a common solution to a split equality monotone variational inclusion problem, a split equality generalized general variational-like inequality problem and a split equality fixed point problem for quasi-nonexpansive mappings in real Hilbert spaces. Some consequences are derived from the main result. Finally, we give a numerical example to justify the main result. The main result extends and unifies some recent known results in the literature.

Key Words and Phrases:Split equality monotone variational inclusion problem, split equality generalized general variational-like inequality problem, split equality fixed point problem, iterative method.
\end{abstract}

2010 Mathematics Subject Classification: 47H09, 47J05, 47J25, 49J40.

Acknowledgments. The authors are extremely grateful to three anonymous referees for their valuable comments and suggestions which improved the manuscript.

\section{REFERENCES}

[1] A. Aleyner, S. Reich, Block iterative algorithms for solving convex feasibility problems in Hilbert and in Banach, J. Math. Anal. Appl., 343(2008), 427-435.

[2] H. Attouch, J. Bolte, P. Redont, A. Soubeyran, Alternating proximal algorithms for weakly coupled minimization problems, Applications to dynamical games and PDEs, J. Convex Anal., 15(2008), 485-506.

[3] H.H. Bauschke, P.L. Combettes, Convex Analysis and Monotone Operator Theory in Hilbert Spaces, Springer, New York, 2011.

[4] C. Byrne, Iterative oblique projection onto convex sets and the split feasibility problem, Inverse Probl., 18(2002), 441-453.

[5] C. Byrne, A unified treatment of some iterative algorithms in signal processing and image reconstruction, Inverse Probl., 20(2004), 103-120.

[6] C. Byrne, Y. Censor, A. Gibali, S. Reich, Weak and strong convergence of algorithms for the split common null point problem, J. Nonlinear Convex Anal., 13(2012), 759-775.

[7] Y. Censor, T. Elfving, A multiprojection algorithm using Bregman projections in a product space, Numer. Algorithms, 8(1994), 221-239. 
[8] Y. Censor, T. Bortfeld, B. Martin, A. Trofimov, A unified approach for inversion problems in intensity modulated radiation therapy, Physics in Medicine and Biology, 51(2006), 2353-2365.

[9] Y. Censor, A. Gibali, S. Reich, Algorithms for the split variational inequality problem, Numer. Algorithms, 59(2)(2012), 301-323.

[10] P.L. Combettes, Hilbertian convex feasibility problem: convergence of projection methods, Appl. Math. Optim., 35(1997), 311-330.

[11] Q.L. Dong, S. He, J. Zhao, Solving the split equality problem without prior knowledge of operator norms, Optimization, 64(9)(2015), 1887-1906.

[12] P. Hartman, G. Stampacchia, On some non-linear elliptic differential-functional equation, Acta Mathenatica, 115(1966), 271-310.

[13] K.R. Kazmi, S.H. Rizvi, Iterative approximation of a common solution of a split equilibrium problem, a variational inequality problem and a fixed point problem, J. Egyptian Math. Soc., 21(2013), 44-51.

[14] K.R. Kazmi, S.H. Rizvi, An iterative method for split variational inclusion problem and fixed point problem for a nonexpansive mapping, Optim. Lett., 8(2014), 1113-1124.

[15] K.R. Kazmi, R. Ali, Hybrid projection method for a system of unrelated generalized mixed variational-like inequality problems, to appear in Georgian Math. J., https://doi.org/10.1515/gmj-2017-0027.

[16] Z. Ma, L. Wang, S.-S. Chang, W. Duan, Convergence theorems for split equality mixed equilibrium problems with applications, Fixed Point Theory Appl., 2015, 2015:31, https://doi.org/10.1186/s13663-015-0281-x.

[17] G. Marino, H.K. Xu, Weak and strong convergence theorems for strict pseudocontractions in Hilbert space, J. Math. Anal. Appl., 329(2007), 336-346.

[18] A. Moudafi, A note on the split common fixed point problem for quasi-nonexpansive operators, Nonlinear Anal., 74(2008), 4083-4087.

[19] A. Moudafi, Split monotone variational inclusions, J. Optim. Theory Appl., 150(2011), 275-283.

[20] A. Moudafi, A relaxed alternating CQ-algorithm for convex feasibility problems, Nonlinear Anal., $\mathbf{7 9}(2013), 117-121$.

[21] A. Moudafi, E. Al-Shemas, Simultaneous iterative methods for split equality problems, Trans. Math. Program. Appl., 1(2)(2013), 1-11.

[22] A. Moudafi, Alternating CQ-algorithm for convex feasibility and split fixed point problems, J. Nonlinear Convex Anal., 15(2014), 809-818.

[23] M.A. Noor, General nonlinear mixed variational-like inequalities, Optimization, 37(1996), 357367.

[24] Z. Opial, Weak convergence of the sequence of successive approximations for nonexpansive mappings, Bull. Amer. Math. Soc., 73(1967), 591-597.

[25] J. Parida, M. Sahoo, A. Kumar, A variational-like inequalitiy problem, Bull. Austral. Math. Soc., 39(1989), 225-231.

[26] V. Preda, M. Beldiman, A. Batatoresou, On variational-like inequalities with generalized monotone mappings, In: Generalized Convexity and Related Topics, Lecture Notes in Economics and Mathematical Systems, 583(2006), 415-431.

[27] B. Qu, N. Xu, A note on the $C Q$ algorithm for the split feasibility problem, Inverse Probl., 21(2005), 1655-1665.

[28] J.C. Yao, The Generalized quasi-variational inequality problem with applications, J. Math. Anal. Appl., 158(1991), 139-160.

[29] J. Zhao, Solving split equality fixed point problem of quasi-nonexpansive mappings without prior knowledge of operator norms, Optimization, 64(2015), 2619-2630.

[30] J. Zhao, S. Wang, Mixed iterative algorithms for the multiple-set split equality common fixedpoint problems without prior knowledge of operator norms, Optimization, 65(2016), 1069-1083.

Received: June 15, 2016; Accepted: January 20, 2017. 
